\title{
Near Eastern ancient bronze objects from Tell Beydar (NE-Suria): insights into their corrosion [Do: 10.105//epn:2007022]
}

\author{
Ivan De Ryck ${ }^{1}$, Emmanuel Pantos ${ }^{2}$ and Annemie Adriaens ${ }^{3, *}$ \\ ${ }^{1}$ Department of Chemistry, University of Antwerp, Campus Drie Eiken, Universiteitsplein $1 \cdot 2610$ Antwerp • Belgium \\ ${ }^{2}$ CCLRC, Daresbury Laboratory • Warrington • UK WA4 4AD \\ ${ }^{3}$ Department of Analytical Chemistry, Ghent University, Krijgslaan 281-S12 • 9000 Ghent • Belgium, Tel: +32 92644826 • Fax: +32 9264 \\ 4960•E-mail: annemie.adriaens@ugent.be \\ ${ }^{*}$ Corresponding author
}

$\mathrm{T}_{\mathrm{s}}^{\mathrm{h}}$ The site of Tell Beydar is located in north-eastern Syria, somewhat $30 \mathrm{~km}$ north of the modern city of Hasake, along the river Khabur (Figure 1) [1]. The history of Tell Beydar starts with the foundation of Nabada, its ancient name, around 2800 BC. Semitic nomad tribes were most probably the founders of this city. A palace was built around $2500 \mathrm{BC}$ and the city passed through a period of great prosperity. At the end of the 25th century BC Tell Beydar was placed under the reign of the kingdom of Nagar (Tell Brak), whose king was visiting Nabada at regular periods in order to participate in certain religious and political events. The city was dominated by Akkadian oppressors during the Akkadian period (2350-2200 BC) and was finally abandoned. The lower parts of the city were again inhabited in $1500 \mathrm{BC}$ by the Mitanni. In the 7th century BC Assyrians built their homes at Tell Beydar. Again Tell Beydar was departed until the Seleucidians and Parthians started to inhabit the upper town in the $4^{\text {th }}$ century ad [2].

Excavations at Tell Beydar have been conducted by a European-Syrian mission under the direction of the European Centre for Upper Mesopotamian Studies in Brussels [3]. All of the bronzes discussed in this work (twenty in total) were excavated during the 1994, 1998 and 1999 field seasons. The samples date to the Early Dynastic II-III period (2700-2300 BC).

In a preceding study, chemical analysis and metallographic examination of a set of copper alloy objects were performed [4]. The objective here was to identify the metals used at Tell Beydar during different periods of occupation. Drawings of the objects are shown in Figure 2. Results showed that four different compositional groups could be distinguished based on their arsenic and tin content: a low arsenic group (As $<2 \mathrm{w} \%$ ), a high arsenic group (As $>2 \mathrm{w} \%$ ), an intermediate tin group (Sn between $3 \mathrm{w} \%$ and $6 \mathrm{w} \%)$ and a high $\mathrm{Sn}$ group $(\mathrm{Sn}>7 \mathrm{w} \%)$. Moreover a clear chronological sequence in the use of copper alloys at Tell Bey-

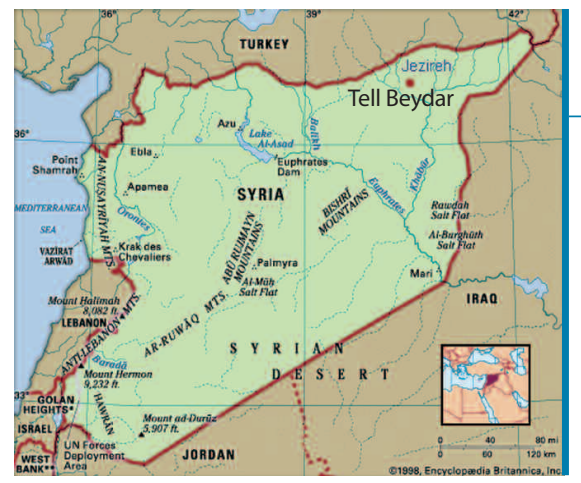

4 Fig. 1: Map of Syria bronzes originating from the EDII period (a), the EDIl period (b) and the Akkadian, Mitanni and Secludic Parthic periods (c) The scale bar at the right hand side of each object indicates a length of $1 \mathrm{~cm}$. dar could be observed. Throughout the EDII period (2700-2600 $\mathrm{BC}$ ) low and high arsenical bronzes were in use simultaneously, while there is clearly no evidence of the presence of tin bronzes. Later, during the EDIII period (2600-2300 BC), tin bronzes come into use and the presence of high arsenical bronzes ceases. Finally during the Akkadian (2300-2200 BC) period results show that both tin bronzes and high arsenical bronzes are no longer present. The fact that Tell Beydar was part of another kingdom during this Akkadian period is a possible explanation for the disappearance of the tin bronzes. Later on, during the Seleucid and Parthian occupation (400 BC - 200 AD), tin bronzes appear again in the metal repertoire of Tell Beydar. Apart from these conclusions the results also indicated that the studies of Tell Beydar bronzes have possibly a different provenance. The study of the microstructure revealed that, in general, the same basic working techniques were used during the period studied. Basically the rough shape of the object was formed by casting the liquid metal into a mould. The object was hammered into shape, both cold and hot, after cooling down. Although it is clear that the same basic methods were used throughout the various periods, the evolution of the microstructure shows that metal smiths were achieving better control over the process of cold and hot working the metal. At the end of the development period the metal smith knew how to create objects having the same composition but with different properties, especially hardness.

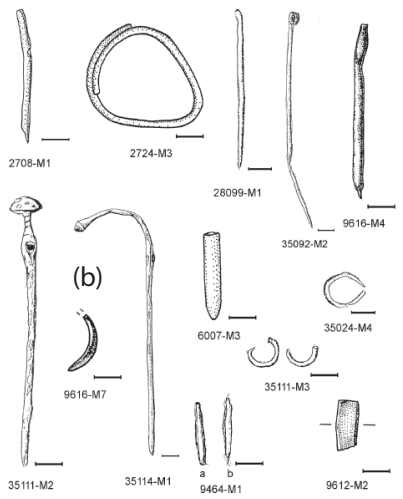

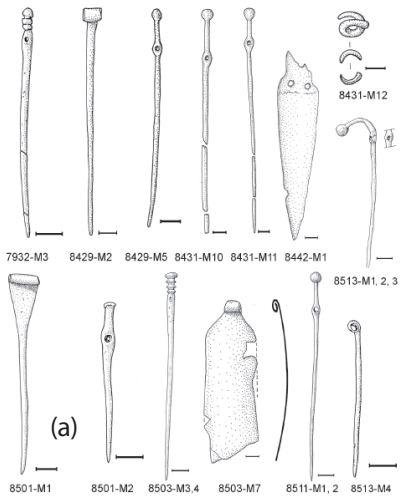

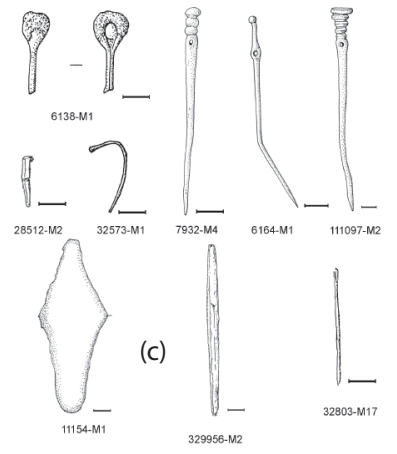


The aim of this work was to study the influence of the alloying elements on the corrosion behaviour. Numerous studies deal with corrosion products on copper-tin alloys [5-7]. Information on the corrosion of copper arsenic alloys, however, is very scarce. In this work the assumption has been made that the corrosive environment to which all the studied bronzes were exposed was approximately the same, as most of the bronzes studied originate from burial sites in the same geological region. Hence, the original composition of the bronzes will be considered as the main variable affecting the corrosion, although it needs to be realised that other factors (i.e. temperature, burial depth, position of the objects in relation to other objects and the presence of certain micro-organisms in the soil) besides the composition can have a possible effect.

\section{Experimental}

A total of 20 objects were analyzed. Their chemical bulk composition as measured by scanning electron microscopy with an energy dispersive spectrometer (SEM-EDS) is listed in Table 1 [4]. Small samples $(3-4 \mathrm{~mm}$ ) were carefully removed using a jeweller's piercing saw. Prior to any sample preparation treatment, a stereo optical light microscope was used to obtain a visual description of the corroded surface. The samples were consequently embedded in an epoxy resin, after which they were ground using silicon carbide and polished with diamond sprays of decreasing grain sizes down to $0.25 \mu \mathrm{m}$. The cross-sections obtained in this way were investigated using an Olympus LM SZX-12 optical research stereomicroscope equipped with a digital camera system DP 10 to obtain in a rapid manner visual information about the structure of the corrosion layer. The same samples were used for SEM-EDS measurements, while thin sections with a thickness of about $300 \mu \mathrm{m}$ were prepared for the synchrotron radiation X-ray diffraction (SR-XRD) analysis.

\begin{tabular}{|c|c|c|c|c|c|c|c|c|c|c|}
\hline Type & Sample & $\begin{array}{l}\text { Archaeological } \\
\text { Number }\end{array}$ & $S$ & $\mathrm{Fe}$ & $\mathrm{Ni}$ & $\mathrm{Cu}$ & As & Sn & $\mathrm{Sb}$ & $\mathrm{Pb}$ \\
\hline \multirow{3}{*}{$\begin{array}{l}\text { Low } \\
\text { arsenical } \\
\text { bronzes }\end{array}$} & $\mathrm{n} 17$ & 35024-M4 & 0.02 & 0.33 & 0.18 & 98.95 & 0.51 & - & - & - \\
\hline & n34 & 35170-M1 & 0.80 & 0.58 & - & 98.29 & 0.33 & - & - & - \\
\hline & n36 & 28099-M1 & 0.59 & 0.18 & 0.10 & 98.72 & 0.41 & - & - & - \\
\hline \multirow{8}{*}{$\begin{array}{l}\text { Intermediate } \\
\text { arsenical } \\
\text { bronzes }\end{array}$} & B4 & 9616-M4 & 0.17 & 0.36 & 0.08 & 98.04 & 1.22 & 0.10 & 0.04 & - \\
\hline & B11 & 9620-M3 & 0.05 & 0.55 & - & 98.20 & 1.21 & - & - & - \\
\hline & B16 & 32573-M3 & 0.17 & 0.52 & - & 96.98 & 1.95 & - & 0.34 & - \\
\hline & Bey20 & 8513-M4 & 0.16 & 0.59 & - & 97.79 & 1.28 & 0.05 & 0.14 & - \\
\hline & n5 & 35114-M1 & 0.06 & 0.26 & - & 98.66 & 1.02 & - & - & - \\
\hline & n29 & 32956-M2 & 0.29 & 0.78 & - & 97.72 & 1.21 & - & - & - \\
\hline & B9 & 9616-M7 & 0.56 & 0.28 & 0.08 & 96.60 & 1.69 & 0.37 & 0.42 & - \\
\hline & n6 & 35111-M2 & 0.27 & 0.33 & 0.07 & 97.41 & 1.35 & 0.48 & 0.09 & - \\
\hline \multirow{2}{*}{$\begin{array}{l}\text { High arsenical } \\
\text { bronzes }\end{array}$} & n7 & 35111-M3 & - & 0.29 & - & & 97.13 & 2.58 & - & - \\
\hline & n31 & 35092-M2 & 0.03 & 0.75 & - & 96.41 & 2.36 & 0.14 & 0.28 & - \\
\hline \multirow{7}{*}{ Tin bronzes } & B18 & 28018-M1 & 0.04 & 0.02 & 0.45 & 92.66 & 0.51 & 6.82 & - & - \\
\hline & B22 & 9612-M2 & - & 0.12 & - & 93.33 & 0.33 & 6.23 & - & - \\
\hline & B23 & 9464-M1 & 0.32 & 0.48 & - & 94.64 & 1.16 & 3.40 & - & - \\
\hline & $n 25$ & 32803-M17 & 0.17 & 0.25 & 0.37 & 95.86 & 2.40 & 0.95 & - & - \\
\hline & n30 & 28512-M2 & 0.11 & 0.15 & 0.51 & 93.23 & 0.77 & 5.22 & - & - \\
\hline & n33 & 35152-M3 & 0.46 & 0.80 & 0.32 & 85.99 & 1.47 & 4.77 & - & 6.18 \\
\hline & n37 & 32907-M2 & 0.06 & 0.23 & 0.60 & 90.09 & 0.68 & 7.70 & - & 0.73 \\
\hline
\end{tabular}
tance of $15 \mathrm{~mm}$ and a detector to sample distance of $50 \mathrm{~mm}$. The X-ray acquisition mode was set to fast mapping and the acquisition time was typically between 30 and 60 min.

The SR-XRD measurements were performed at station 9.6 of the Synchrotron Radiation Source (SRS) at Daresbury Laboratory, U.K. An intense beam was used (ca 100 s collecting time during single-bunch mode and beam current $>20 \mathrm{~mA}$ ), with high energy (i.e. high penetration) photons $(E=14.25 \mathrm{keV}, \lambda=0.87 \AA)$ and a small beam footprint $(100 \mu \mathrm{m})$ defined by collimator slits. The XRD patterns were collected in transmission by a QUANTUM-4 CCD area detector. A microscope alignment system allowed the location of the beam on the desired part of the sample. Data analysis was carried out using the ESRF package FIT2D [9] and reference data from the JCPDS PDF cards were used to identify the corrosion compounds.

4 Table 1: Elemental composition of the analyzed samples (wt\%) measured using SEM-EDS. The error is below 10\%, except for sulphur which is below 30\%. - means below detection limits. 


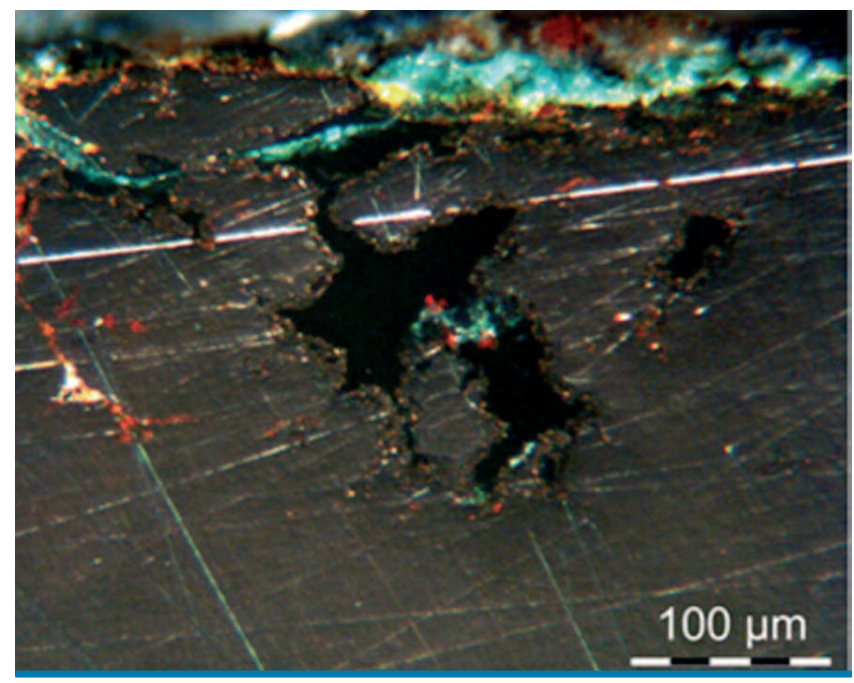

$\Delta$ Fig. 4: Optical micrograph of a cross section of sample $n 17$.

\section{Results and discussion}

Bronzes with a low arsenic content

A total of 3 samples with an arsenic content below $1 \mathrm{wt} \%$ were analysed. Table 1 lists their elemental composition showing only minor differences in their composition. Experiments on the corroded surface with the above mentioned analytical techniques demonstrate that the corrosion crust consists of various layers (not clearly separated), with a total of about $200-500 \mu \mathrm{m}$ in thickness. The crust is composed of malachite $\left(\mathrm{CuCO}_{3} \cdot \mathrm{Cu}(\mathrm{OH})_{2}\right)$ with embedded soil particles, underneath cuprite $\left(\mathrm{Cu}_{2} \mathrm{O}\right)$ and nantokite $(\mathrm{CuCl})$. Table 2 summarizes the typical corrosion features encountered on low arsenical bronzes and is in what follows elaborated in more detail.

Figure 3 shows an optical image obtained from the surface of sample n17, demonstrating the presence of dark brown to orange cuprite. In addition, light green corrosion products can be distinguished covered by white compounds which are probably remaining soil particles. Optical micrographs obtained from cross-sections of the samples visualize the structure of the corrosion crust (Figure 4). The most remarkable feature is the advanced intergranular corrosion. In addition the pitting corrosion can be observed as a green layer (nantokite) in contact with the metal. This layer is followed by a reddish cuprite layer, with on top green corrosion compounds (malachite). This corrosion pattern is typical for bronze disease [10].

The results are confirmed by the elemental distribution patterns obtained with SEM-EDS (Figure 5). A chloride layer in direct contact with the metal can be observed in the X-ray maps. The chloride layer is covered by a cuprite layer and by a layer that contains copper and soil elements such as silicon.

XRD patterns were recorded along a line starting from the outer layer into the bulk metal. Results show the following sequence of corrosion compounds: (a) malachite; (b) malachite, cuprite; (c) malachite, cuprite, nantokite; (d) cuprite, nantokite. This sequence implies that the corrosion crust is composed of three layers: a malachite layer, a cuprite layer and a nantokite layer. Similar results were found for the other samples in the same group. In Figure 6, a typical diffractogram is shown.

Bronzes with an intermediate arsenic content

Eight bronzes with an intermediate-arsenic content (between
1 and $2 \mathrm{wt} \%)$ were analysed. The chemical bulk composition of the bronzes is again listed in Table 1 and shows a close similarity, except for 2 bronzes, n6 (35111-M2) and B9 (9616-M7), which have higher contents of tin and antimony (the sum of both elements being above $0.5 \mathrm{wt} \%$ ).

The corroded surfaces of the studied bronzes are all similar in appearance, mainly consisting of green, red and black corrosion compounds together with white soil particles. Optical micrographs of the cross-sections of the samples show two different corrosion structures: (1) a three-layered structure of 1000-2000 $\mu \mathrm{m}$ thickness for the majority of the samples and (2) a two layered intergranular corrosion structure of 300-500 $\mu \mathrm{m}$ thickness for both samples with higher contents of tin and antimony.

Results show that the three-layered structure consists of (1) a black to grey nantokite layer in direct contact with the metal; (2) a red cuprite layer; (3) a green layer of malachite with calcite and quartz particles. The two-layered structure consists of (1) a top layer of malachite and soil and intergranular corrosion composed of cuprite and nantokite which is depleted in arsenic and penetrates into the bulk of the metal. An overview of the results is given in Table 3.

\section{Bronzes with a high arsenic content}

Only two bronzes with a high arsenic content were available that had not been previously cleaned, meaning that only these are suitable for this study. Table 1 shows their composition. In contrast to the previous samples with a low and intermediate arsenic contact, it was clear that both samples showed a significant difference in corrosion structure. Sample n7 (35111-M3) is almost completely corroded while sample n31 (35092-M2) is hardly affected by corrosion. Table 4 gives an overview of the results obtained.

\section{Tin bronzes}

A total of 7 bronzes with a tin content above $1 \mathrm{wt} \%$ were analysed. Their chemical bulk composition is given in Table 1. Optical micrographs of the surface show compounds with different shades of green and blue, as well as red compounds and white soil particles. Cross-sections show two different corrosion structures: (1) intergranular corrosion enriched in tin and (2) a three-layered corrosion composed of malachite, paratacamite, cuprite, nantokite and cassiterite. Table 5 summarizes typical corrosion features observed for both corrosion structures.

Fig. 5: X-ray maps of sample $n 17$ showing the elemental distribution of (a) $\mathrm{Al}$, (b) Si, (c) Mg, (d) Ca, (e) Cl and (f) Cu.
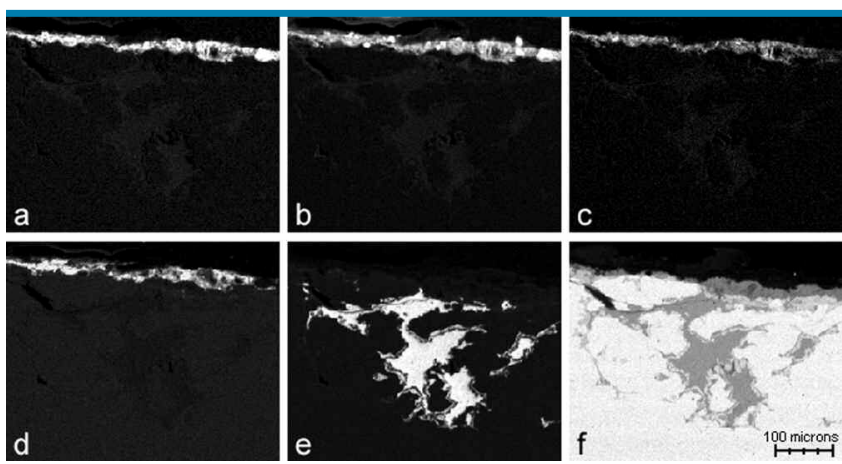


\section{Intergranular corrosion}

The BSE image in Figure 7 illustrates the intergranular character of the corrosion as it occurs for most of the tin bronzes. Xray images of sample B22 (Figure 8) show that chloride surrounds the central part of the sample containing the intergranular corrosion. The chloride containing layer is covered by a surface layer which contains copper and soil elements. At the interface between the outer layer and the internal layer, tin is enriched. Additional SR-XRD analyses show the presence of the minerals quartz $\left(\mathrm{SiO}_{2}\right)$, calcite $\left(\mathrm{CaCO}_{3}\right)$, kaolinite and montmorillonite (both of them phyllosilicates) in the outer layer of the sample. Underneath this layer, cuprite, nantokite and cassiterite

$\nabla$ Table 2: Corrosion characteristics of low arsenical bronzes

\begin{tabular}{|l|l|}
\hline Layer structure & $\begin{array}{l}\text { no clearly separated layers } \\
\text { irregular intergranular corrosion }\end{array}$ \\
\hline Thickness & $200-500 \mu \mathrm{m}$ \\
\hline Surface appearance & $\begin{array}{l}\text { light green powdery and red crystalline compounds } \\
\text { white soil particles }\end{array}$ \\
\hline Major compounds & $\begin{array}{l}\text { soil, malachite } \\
\text { cuprite, nantokite }\end{array}$ \\
\hline Samples & $\mathrm{n} 17, \mathrm{n} 34, \mathrm{n} 36$ \\
\hline
\end{tabular}

$\nabla$ Table 3: Corrosion characteristics of intermediate arsenical bronzes

\begin{tabular}{|l|l|l|}
\hline Layer structure & $\begin{array}{l}3 \text { layers } \\
\text { evenly structured }\end{array}$ & $\begin{array}{l}\text { 2 layers } \\
\text { intergranular corrosion } \\
\text { depleted in arsenic }\end{array}$ \\
\hline Thickness & $500-1000 \mu \mathrm{m}$ & $300-500 \mu \mathrm{m}$ \\
\hline Surface appearance & $\begin{array}{l}\text { green, red and black corrosion compounds } \\
\text { white soil particles }\end{array}$ \\
\hline Major compounds & $\begin{array}{l}\text { malachite, quartz, calcite } \\
\text { cuprite } \\
\text { nantokite }\end{array}$ & $\begin{array}{l}\text { malachite, soil } \\
\text { cuprite, nantokite }\end{array}$ \\
\hline Samples & n5, n29,B4,B16,B11,Bey20 & n6,B9 \\
\hline
\end{tabular}

$\nabla$ Table 4: Corrosion characteristics of high arsenical bronzes

\begin{tabular}{|l|l|l|}
\hline Layer structure & 3 layers & Alternating structure \\
\hline Thickness & $\begin{array}{l}\text { almost completely } \\
\text { corroded }\end{array}$ & $<100 \mu \mathrm{m}$ \\
\hline Surface appearance & $\begin{array}{l}\text { bright green to blue } \\
\text { corrosion } \\
\text { red crystalline compounds }\end{array}$ & $\begin{array}{l}\text { green and brownish } \\
\text { red compounds }\end{array}$ \\
\hline Major compounds & $\begin{array}{l}\text { malachite, soil } \\
\text { arsenic enrichment layer } \\
\text { cuprite } \\
\text { nantokite }\end{array}$ & $\begin{array}{l}\text { nantokite } \\
\text { cuprite }\end{array}$ \\
\hline Samples & $\mathrm{n7}$ & $\mathrm{n} 31$ \\
\hline
\end{tabular}

$\nabla$ Table 5: Corrosion characteristics of tin bronzes

\begin{tabular}{|l|l|l|}
\hline Layer structure & $\begin{array}{l}\text { 2 layers } \\
\text { intergranular corrosion }\end{array}$ & $\begin{array}{l}\text { 3 layers } \\
\text { evenly structured }\end{array}$ \\
\hline Thickness & $100-1000 \mu \mathrm{m}$ & far advanced corrosion \\
\hline Surface appearance & $\begin{array}{l}\text { white soil compounds } \\
\text { red crystalline compounds } \\
\text { corrosion with different shades of green and blue } \\
\text { brown to black corrosion }\end{array}$ \\
\hline Major compounds & $\begin{array}{l}\text { different copper } \\
\text { alteration compounds } \\
\text { intergranular } \\
\text { enrichment in tin }\end{array}$ & $\begin{array}{l}\text { brochantite, paratacamite } \\
\text { cuprite } \\
\text { nantokite, cassiterite }\end{array}$ \\
\hline Samples & $\mathrm{n} 25, \mathrm{n} 30, \mathrm{n} 33, \mathrm{~B} 22$ & $\mathrm{~B} 18, \mathrm{~B} 23$ \\
\hline
\end{tabular}

$\left(\mathrm{SnO}_{2}\right)$ were identified. The observations made for the tin bronze here are comparable to results described by Robbiola [5].

\section{Layered corrosion}

Two of the tin bronzes showed a layered corrosion structure. The results are very similar to the three-layered structure of the intermediate-arsenic content bronzes: a nantokite layer in direct contact with the bulk metal is covered by a cuprite layer which is covered by an outer layer containing calcite, quartz and copper alteration products. The alteration product of copper in the outer layer was identified by SR-XRD to be brochantite $\left(\mathrm{Cu}_{4}\left(\mathrm{SO}_{4}\right)(\mathrm{OH})_{6}\right)$ and paratacamite $\left(\mathrm{Cu}_{2}(\mathrm{OH})_{3} \mathrm{Cl}\right)$, an observation which is different from those for the arsenical bronzes where malachite was the major corrosion compound of copper. The presence of brochantite is surprising as it is well known that it occurs mainly on bronzes exposed to an atmospheric environment and is rarely observed for bronzes buried into the soil [5]. One possible explanation for this different behaviour between the arsenical and the tin bronzes is that the brochantite was formed after the excavation, an assumption supported by the fact that the bronze disease, at least for sample B18, is active in contrast to the other examined samples where it is passive. The presence of paratacamite, an alteration product of nantokite, supports the hypothesis of the activated bronze disease.

\section{Conclusions}

The corrosion of the Tell Beydar bronzes was investigated using a variety of analytical methods. The results show that the structure and the composition of the corrosion are influenced by the original composition of the bronze alloy.

In general the corrosion observed on the bronzes is controlled by the presence of chlorides in direct contact with the metal. This type of corrosion is well known as "bronze disease". Although this corrosion is known to be generally very active, it was not yet in the active state for the examined bronzes. This is demonstrated by the absence of copper trihydroxychlorides (e.g. atacamite and paratacamite). Nevertheless in the future care must be taken to preserve the bronzes after excavation. It is well known that the corrosion of bronzes containing chlorides in contact with the metal is readily activated in the presence of humidity. Therefore conservation scientists advise to store the bronzes in relative dry conditions (below $40 \%$ of relative humidity).

The corrosion of bronzes with a low arsenic content does not show in general a clearly layered structure. Intergranular corrosion covered by an outer corrosion layer was observed, which is composed of nantokite and cuprite while the outer corrosion layer contains the compounds cuprite and malachite.

Layered corrosion structures were observed for bronzes containing arsenic between 1 and $2 \mathrm{wt} \%$. In this case a three-layered structure could be distinguished consisting of a nantokite layer in direct contact with the metal, followed by a cuprite layer and layer containing malachite and some minerals originating from the soil such as quartz and calcite. Two samples with an intermediate arsenic content, however, show a different corrosion structure, of the two-layered kind of structure. The difference in corrosion structures for the intermediate-arsenical bronzes is most probably due to 


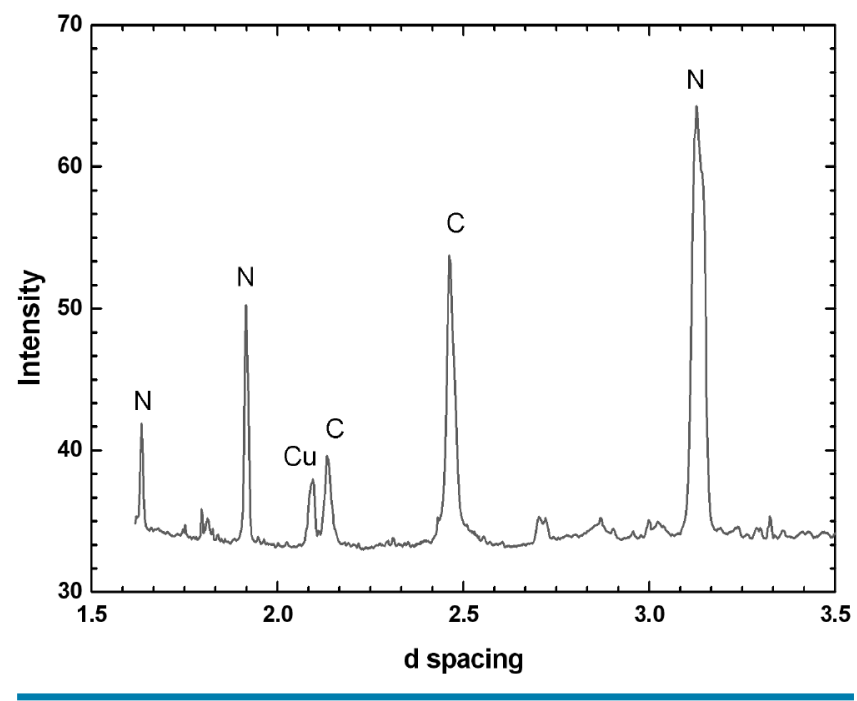

$\Delta$ Fig. 6: Diffractogram of the corrosion of sample n17.

differences in composition. In the case of the two-layered corrosion structure the bronzes contained copper and arsenic and smaller amounts of antimony and tin.

The corrosion of the tin bronzes consists mainly of an intergranular structure, with is enriched in tin. Tin is also enriched at the interface of internal corrosion with the outer corrosion layer, which forms evidence for the selective dissolution of tin from the alloy. Also tin bronzes with a three-layered corrosion structure similar to the corrosion structure on intermediate-arsenical bronzes were observed, be it with different compounds: the outer layer containing brochantite instead of malachite. The layer in direct contact with the metal contains nantokite and cassiterite. The similarity in corrosion structure between the tin and arsenical bronzes illustrates that, in addition to the composition of the bronze as a factor influencing the corrosion, other factors such as for example the corrosive environment are also of importance..

\section{Acknowledgements}

The authors thank M. Lebeau (European Centre for Upper Mesopotamian Studies, Brussels) and K. Van Lerberghe (K.U. Leuven) for kindly providing the archaeological objects. The
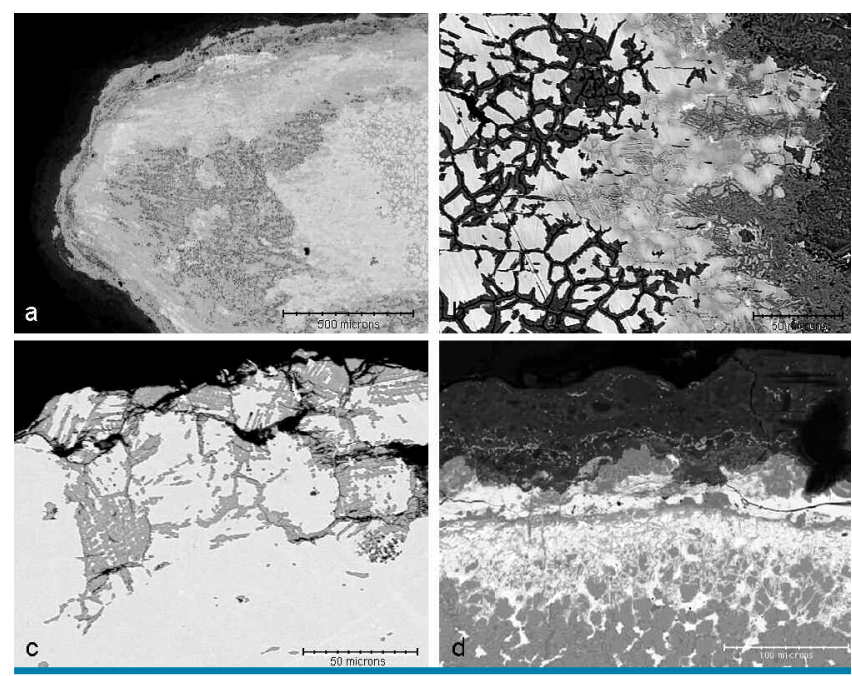

A Fig. 7: BSE images of samples (a, b) B22, (c) n30 and (d) n33, illustrating the intergranular character of the corrosion. present work was partly supported by SRS Daresbury (EU FMP6 grant no. 39114).

\section{About the authors}

Ivan De Ryck graduated with a $\mathrm{PhD}$ in Analytical Chemistry in 2003 from the University of Antwerp. His principal interest involved the archaeometallurgical study of objects from the site Tell Beydar (Syria).

Emmanuel Pantos obtained his $\mathrm{PhD}$ in 1973 at the Physics Department of Manchester University. He now works at Daresbury Laboratory (UK) where he is head of the Archaeometry Unit.

Annemie Adriaens is professor in Analytical Chemistry at Ghent University (Belgium) where she leads the research group "Electrochemistry and Surface Analysis". She is chair of the pan-European COST Action G8 "Non-destructive Analysis and Testing of Museum Objects".

\section{References}

[1] M. Lebeau, J. Bretschneider, Urbanisme en Architectuur, in: M. Lebeau, P. Talon, K. Van Lerberghe (Eds.), Syrië: Naar de Oorsprong van het Schrift, Brepols Publisher, Turnhout, 1997, pp.151.

[2] J. Bretschneider, M. Lebeau, P. Tallon, K. Van Lerberghe, Tell Beydar in de Mesopotamische wereld, in: M. Lebeau, P. Tallon and K. Van Lerberghe (Eds.), Syrië. Naar de Oorsprong van het Schrift, Brepols Publisher, Turnhout, 1997, pp. 179.

[3] M. Lebeau, La Situation Géographique, Tell Beydar, Three Seasons of Excavations (1992-1994): A preliminary Report., A. Suleiman (eds.), Subartu III, Turnhout, Brepols Publisher, 1997, pp. 7.

[4] I. De Ryck, A. Adriaens, F. Adams, "Microanalytical metal technology study of ancient Near Eastern bronzes from Tell Beydar", Archaeometry 45 (2003) 579.

[5] L. Robbiola, J.-M. Blengino, C. Fiaud, Corrosion Science 40 (1998) 2083.

[6] V.F. Lucy, British Corrosion Journal 7 (1972) 36.

[7] L. Robbiola, L. Hurtel, Metal 95: International Conference on Metals Conservation, Science publishers Ltd., London, 1997, pp. 109.

[8] I. De Ryck, A. Adriaens, E. Pantos, F. Adams, Analyst 128 (2003) 1104.

[9] A.P. Hammersley, O. Svensson, M. Hanfland, A.N. Fitch, D. Hausermann, High Pressure Research 14 (1996) 235.

[10] D.A. Scott, Copper and Bronze in Art: Corrosion, Colorants, Conservation, The Getty Conservation Institute, Los Angeles, 2002.
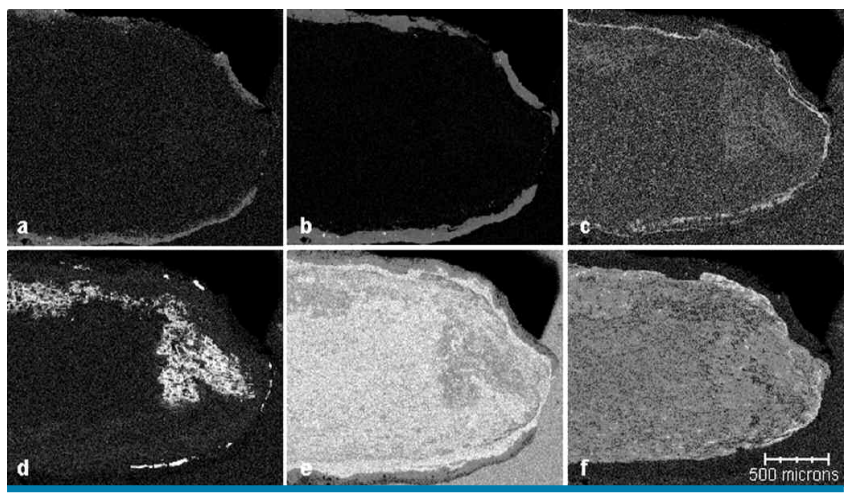

$\Delta$ Fig. 8: X-ray map of sample B22 showing the elemental distribution of (a) $\mathrm{Al}$, (b) $\mathrm{Si}$, (c) $\mathrm{S}$, (d) $\mathrm{Ca}$, (e) Cl and (f) $\mathrm{Sn}$. 